\title{
CAMPUR KODE DALAM INTERAKSI MASYARAKAT DESA BOLADANGKO KECAMATAN KULAWI KABUPATEN SIGI
}

\author{
Ferdiawan \\ Dosen Fakultas Ekonomi dan Bisnis Islam Institut Agama Islan Negeri (IAIN) Palu \\ ferdiawan@iainpalu.ac.id
}

\begin{abstract}
Based on the formulation of the problem of this research is how the form of code mixing in the interaction of Boladangko village community in the Kulawi district of Sigi district and the factors driving the code mix in the Community Interaction of Boladanko Village in the Kulawi District of Sigi district. The purpose of this study was to determine the form of mixed code speech in the interaction of Boladanko village, Kulawi sub-district, Sigi district. The method used in this study is a qualitative method. Qualitative research methods are intended to describe the form of mixed code speech in the Boladangkokececity of Kulawi Sub-district, Sigi Regency. Based on the results of the study the authors found a mixture of the Kaili language code (Moma) and Indonesian. Mix the code because the speaker forgets the language of his area so that the speaker sometimes deliberately interferes with the code because of the habits and the ease of speech and changes in the way of communication between the speaker and the interlocutor. The following is code mixing data that occurs in the process of community interaction in Boladangko Village, Kulawi Subdistrict, Sigi Regency based on word class, namely, insertion of affixed elements, insertion of elements in the form of clauses, insertion of elements in the form of words and insertion of elements in the form of phrases. The driving factor for code mixing has more to do with the speaker, the speech partner, the function and purpose of the speaker, and the situation of the conversation. The driving factors for code mixing are extralinguistic and intralinguistic factors. Extralinguistic factors related to the character of the speaker such as background, social, religious sense, level of education, and regionalism. Intralinguistic factors relate to the absence of words in the Moma language that are capable of overseeing the concept referred to as the linguistic element that is inserted.
\end{abstract}

Key words: Code mixing, community interaction 


\section{Abstrak}

Berdasarkan rumusan masalah penelitian ini adalah bagaimana wujud campur kode dalam interaksi masyarakat desa Boladangko kecematan Kulawi kabupaten Sigi serta faktor-faktor pendorong campur kode dalam Interaksi Masyarakat Desa Boladanko Kecamatan Kulawi kabupaten Sigi. Tujuan penelitian ini adalah untuk mengetahui wujud tuturan campur kode dalam interaksi masyarakat Desa Boladanko kecamatan Kulawi kabupaten Sigi. Metode yang diguanakan dalam penelitian ini adalah metode kualitatif. Metode penelitian kualitatif dimaksudkan untuk mendeskribsikan wujud tuturan campur kode yang terdapat dalam masyarakat Boladangkokecamatan Kulawi kabupaten Sigi. Berdasarkan hasil penelitian penulis menemukan adanya campur kode bahasa Kaili bahasa (Moma) dan bahasa Indonesia. Campur kode tersebut karena penutur lupa dengan bahasa Daerahnya sehingga penutur terkadang sengaja melakukan campur kode karena kebiasaan dan kesantaian berbicara serta perubahan cara berkomunikasi antara penutur dan lawan tuturnya. Berikut Data campur kode yang terjadi dalam proses interaksi masyarakat Desa Boladangko kecamatan kulawi kabupaten Sigi berdasarkan kelas kata yaitu, Penyisipan unsur yang berwujud afiks, penyisipan unsur yang berwujud klausa, penyisipan unsur yang berwujud kata dan penyisipan unsur yang berwujud frasa. Faktor pendorong campur kode lebih berkaitan dengan pembicara, mitra tutur, fungsi dan tujuan pembicara, dan situasi pembicaraan. Faktor pendorong campur kode yaitu faktor ekstralinguistik dan intralinguistik. Faktor ekstralinguistik berhubungan dengan karakter pembicara seperti latar belakang, sosial, rasa keagamaan, tingkat pendidikan, dan rasa kedaerahan. Faktor Intralinguistik berhubungan dengan tidak adanya kata dalam bahasa Moma yang mamapu mewahanai konsep yang dimaksud unsur kebahasaan yang disisipkan.

Kata kunci: Campur kode, interaksi masyarakat

\section{Pendahuluan}

Bahasa Indonesia adalah bahasa pemersatuan yang resmi digunakan sebagai alat komunikasi dalam keberagaman budaya yang merupakan ciri khas bangsa. Bahasa ini mempersatukan manusia dalam hubungan sosial dan komunikasi antara individu yang satu dengan individu lainnya. 
Indonesia merupakan Negara yang memiliki keberagaman baik suku, budaya dan bahasa. meskipun Indonesia memiliki tiga kelompok bahasa, yaitu bahasa nasional, bahasa daerah, dan bahasa asing. Keberagaman ini bukan menjadi tembok raksasa yang menghalangi setiap orang Indonesia dalam berkomunikasi. Kedudukan dan fungsi bahasa Indonesia dan bahasa daerah terangkum dalam Rumusan Seminar Politik Bahasa.

Bagi sebagian besar penduduk Indonesia, bahasa daerah merupakan bahasa pertama yang dikuasai sejak mereka mengenal bahasa atau mulai dapat berbicara. Mereka menggunakan bahasa daerah untuk berkomunikasi dan berinteraksi intra suku, baik dalam situasi yang bersifat resmi maupun yang bersifat tidak resmi (kedaerahan). Tiap-tiap etnik memiliki bahasa daerah sebagai identitas kelompoknya. Dengan demikian, dapat dibayangkan betapa banyak bahasa daerah yang ada di indonesia.

Ada juga penduduk Indonesia yang menjadikan bahasa Indonesia sebagai bahasa pertama dan bahasa daerah sebagai bahasa keduanya. Kedua bahasa tersebut digunakan saling bergantian sesuai situasi dan kondisi untuk berkomunikasi dan melakukan percakapan sehari-hari. Kemampuan menguasai bahasa pertama dan bahasa kedua ini menjadikan masyarakat Indonesia menjadi masyarakat yang multilingual artinya masyarakat yang menguasai lebih dari dua bahasa. Ketika melakukan kontak bahasa, mereka mengalami masalah kebahasaan seperti alih kode dan campur kode.

Dalam aspek linguistik masyarakat Indonesia merupakan masyarakat yang bilingual (dwibahasa) yang menguasai lebih dari satu bahasa yaitu bahasa daerah, bahasa Indonesia dan bahasa Asing. (Nababan,1989:27) masyarakat yang dwibahasa akan mengalami kontak bahasa Indonesia sehingga melahirkan campur kode ${ }^{1}$.

Penguasaan dua bahasa atau lebih dapat mempermudah seseorang dalam tindak komunikasi misalnya pada objek kajian yang diambil oleh peneliti tentang tindak bahasa di Desa Boladangko Kecamatan Kulawi, yakni tindak bahasa yang dilakukan oleh masyarakat dalam melakukan transaksi atau melakukan percakapan dalam kehidupan sehari-hari dilingkungan masyarakat.

\footnotetext{
${ }^{1}$ Nababan, P.W. J. Sosio Linguistik Suatu Pengantar. (Jakarta: PT. Gramedia 1986), h. 29
} 
Tindak bahasa yang dilakukan oleh masyarakat Desa Boladangko Kecamatan Kulawi dalam berkomunikasi sering terjadi campur kode/percampuran dua (lebih) bahasa. Percampuran tersebut biasa terjadi karena pelaku tindak bahasa menguasai dua bahasa atau biasa juga dilakukan dengan sengaja karena belum menguasai suatu bahasa kemudian mencari padanan kata yang tidak dimengerti tersebut. Selain itu, campur kode juga biasa dilakukan untuk mempermudah atau memperlancar tindak komunikasi yang dilakukan oleh pelaku tindak komunikasi.

Hari demi hari mereka melakukan adaptasi dengan keluarga yang lebih sering menggunakan bahasa Indonesia saat berkomunikasi. Mereka akan menggunakan bahasa kulawi ketika berbicara dengan anggota keluarga yang lebih tua. Mereka juga melakukan pergantian bahasa, dari bahasa kulawi ke bahasa Indonesia ketika melakukan interaksi dengan keluarga yang tinggal dan lahir dikulawi.

Pergantian bahasa inilah yang memunculkan peristiwa campur kode. Ketika lupa atau tidak tahu sebuah kata dari bahasa Indonesia, mereka akan menggunakan kata dari bahasa kulawi untuk berkomunikasi sambil menjelaskan maksud yang ingin disampaikan.

Dari pengamatan dan penghayatan penulis sebagai anggota masyarakat Boladangko selama bertahun-tahun, dapat dikatakan bahwa bahasa yang terdapat dalam masyarakat di wilayah desa Boladangko Kecamatan Kulawi juga memiliki fungsi dan peran yang berbeda-beda. Misalnya fungsi bahasa masyarakat boladangko dalam konteks resmi seperti upacara perkawinan dan kematian berperan sebagai bahasa yang memiliki variasi tinggi.

Masyarakat desa Boladangko selain merupakan bilingual juga merupakan masyarakat diglosik. Pada masyarakat tutur yang demikian memang relavan dan amat menarik untuk diteliti dan dideskripsikan pemakaian campur kode bahasanya. Dikatakan relevan dan menarik karena didalam masyarakat itu sering menggunakan perpindahan bahasa satu dengan lainnya sesuai konteks.

Berikut contoh campur kode yang terjadi disebuah kios desa boladangko.

Penutur 1 : “Anta, naria dihandalamu ei?" 
Penutur 2 : "Naria, mau yang nomor berapa?"

Penutur 1 : "Nomor tiga puluh delapan ada?

Penutur 2 : "Coba mu hilo ritu, pilih-pilih moto moko ritu mama Nuning"

Penutur 1 : "yang warna hitam ini berapa harganya?"

Penutur 2 : "Rp.35.000 itu. Pehoba mi olu”

Penutur 1 : "Alhamdulillah, Na raha dimi pakeku ei"

Diatas telah terjadi percakapan antara penutur 1 dan penutur 2. Dapat dilihat bahwa penjual dan pembeli sama-sama berasal dari suku kaili (uma). Mereka adalah masyarakat di desa Boladangko. Kata yang bercetak miring diatas penanda bahwa terjadinya campur kode bahasa Kaili (uma) ke dalam bahasa Indonesia.

Campur kode terjadi jika penutur menggunakan suatu bahasa secara dominan mendukung suatu tuturan yang disisipi dengan unsur bahasa lainnya. Hal ini biasanya berhubungan karakteristik penutur, seperti latar belakang sosial, tingkat pendidikan dan rasa keagamaan.biasanya ciri yang utama berupa kesantaian atau situasi non formal. Akan tetapi biasanya juga terjadi keterbatasan bahasa, ungkapan dalam bahasa tidak memiliki padanannya sehingga menggunakan bahasa lain.

Desa Boladangko berada dikecamatan kulawi kabupaten sigi, pada umumnya masyarakat atau penduduk didesa ini adalah masyarakat asli di desa boladangko, dan masyarakat setempat menggunakan bahasa kaili khususnya kaili Moma. Akan tetapi biasanya juga terjadi keterbatasan bahasa, ungkapan dalam bahasa tidak memiliki padanannya sehingga menggunakan bahasa Indonesia.

Berdasarkan hal tersebut yang menyebabkan ketertarikan peneliti untuk melakukan penelitian terhadap campur kode bahasa dalam interaksi masyarakat Desa Boladangko, hal ini dikarenakan penggunaan bahasa atau dialek yang menarik dan didukung karena adanya fenomena bahasa campur kode tersebut.

\section{Metode Penelitian}

Jenis penelitian yang digunakan dalam penelitian ini adalah jenis penelitian kualitatif ,yaitu penelitian yang bersifat mendeskripsikan bentuk bahasa campur kode. 
Penelitian yang bersifat deskriptif adalah penelitian yang berisi paparan untuk menggambarkan suatu kejadian atau fenomena yang terjadi oleh sebuah subjek penelitian seperti perilaku, persepsi, motivasi, tindakan secara holistik dan dengan cara deskriptif dalam bentuk kata-kata dan bahasa dengan suatu konteks yang alamiah (Moleong, 2011).

Metode dalam pengumpulan data yang digunakan dalam penelitian ini sebagai berikut:

1. Observasi partisipan dan pencatatan lapangan pencatatan narrative

Observasi partisipan adalah suatu proses pengamatan yang dilakukan oleh observasi dengan ikut mengambil bagian dalam kehidupan orang-orang yang akan diobservasi. dalam hal ini observasi bersungguh-sungguh seperti anggota kelompok yang akan diteliti. Observasi ini akan digunakan untuk mengetahui masalah yang berhubungan langsung dengan bentuk campur kode pada sebuah pertemuan yang nonformal. Sedangkan pencatatan lapangan (pencatatan narative) adalah teknik pengumpulan data (pencatatan) data oleh observasi dengan kajian dan urutan kejadiannya bagaimana yang akan terjadi pada situasi nyata.

2. Wawancara

Wawancara terbuka yaitu suatu teknik pengumpulan data penelitian menyampaikan terlebih dahulu kepada informan mengenai tujuan wawancara dan batasan data yang akan dikumpulkan.

c. Rekam

Rekam yaitu metode pengumpulan data yang digunakan dengan cara merekam percakapan informan, terutama percakapan yang berhubungan dengan penggunaan campur kode dalam peristiwa interaksi campur kode di Desa Boladangko.

d. Catat

Catat yaitu metode pengumpulan data yang digunakan dengan cara mencatat percakapan yang berhubungan dengan campur kode bahasa Indonesia dengan bahasa daerah yang digunakan dengan campur kode bahasa Indonesia dengan bahasa daerah yang digunakan masyarakat Boladangko kecamatan Kulawi Kabupaten Sigi. 


\section{Pengertian Campur Kode}

Yakni peralihan pemakaian dari satu bahasa atau dialek ke bahasa dan dialek lainnya. Alih bahasa ini sepenuhnya terjadi karena perubahan sosiokultural dalam situasi berbahasa. Perubahan ini dimaksud meliputi faktor-faktor seperti hubungan antar pembicara dan pendengar, laras bahasa, tujuan bicara, topik yang dibahas, dan tempat berbincang.

Para penutur yang sedang beralih kode berasal dari minimum komunitas dari bahsa-bahasa (dialek) yang sedang mereka praktekkan. Sebaliknya pergantian (alih) ragam bukan berarti berganti komunitas. Alih ragam terjadi dalam bahasa yang sama karena dorongan perubahan situasi berbicara, topik, status sosial, penutur dan sebagainya.

Dengan demikian dapat dikatakan bahwa alih kode (bahasa atau dialek) dilakukan oleh dua pihak yang memiliki dua komunitas bahasa yang sama.alih ragam hanya terjadi dalam satu bahasa dan satu komuniitas saja.

Hadirnya campur kode merupakan akibat dari kemampuan anggota masyarakat berbahasa lebih dari satu.selain itu bila dua atau lebih bahasa bertemu karena diguankan oleh penutur dari komunitas bahasa yang sama, maka akan terjadi bahwa komponenkomponen tertentu dapat tertransfer dari bahasa yang satu, yakni bahasa sumber (source or donor language). Akibatnya terjadi pungutan bahasa atau "interference" sebagaimana diistilahkan oleh winreich $(1953)^{2}$. Proses terjadinya intrferensi sejalan dengan proses terjadinya difusi kebudayaan (cultural diffusion) yang kita kenal dalam ilmu sosiologi.

\section{Faktor Penyebab Campur Kode}

Campur kode tidak muncul karena tuntutan situasi, tetapi ada hal lain yang menjadi faktor terjadinya campur kode itu. Pada penjelasan sebelumnya telah dibahas menganai ciri-ciri peristiwa campur kode, yaitu tidak dituntut oleh situasi dan konteks pembicaraan, adanya ketergantungan bahasa yang mengutamakan peran dan fungsi

${ }^{2}$ Uriel Weinreich, Languages in contact Findings And Problems ( New York: Mouton Publisher, 1953) 
kebahasaan yang biasanya terjadi pada situasi yang santai. Berdasarkan hal tersebut, Suwito (1983) memaparkan beberapa faktor yang melatarbelakangi terjadinya campur kode yaitu sebagai berikut; ${ }^{3}$

a. Faktor peran

Yang termasuk peran adalah status sosial, pendidikan, serta golongan dari peserta bicara atau penutur bahasa tersebut.

1) Faktor ragam

Ragam ditentukan oleh bahasa yang digunakan oeh penutur pada waktu melakukan campur kode, yang akan menempat pada hirarki status sosial.

2) Faktor keinginan untuk menjelaskan dan menafsirkan

Yang termasuk faktor ini adalah tampak pada peristiwa campur kode yang menandai sikap dan hubungan penutur terhadap orang lain, dan hubungan orang lain terhadapnya.

Jendra (1991: 134-135) mengatakan bahwa "setiap peristiwa wicara (speech event) yang mungkin terjadi atas beberapa tindak tutur (speech act) akan melibatkan unsur: pembicara dan pembicara lainnya (penutur dan petutur), media bahasa yang digunakan, dan tujuan pembicaraan".

Lebih lanjut, Jendra (1991) menjelaskan bahwa ketiga faktor penyebab itu dapat dibagi lagi menjadi dua bagian pokok, umpamanya peserta pembicaraan dapat disempitkan menjadi penutur, sedangkan dua faktor yang lain (faktor media bahasa yang digunakan dan faktor tujuan pembicaraan) dapat disempit lagi menjadi faktor kebahasaan;

\section{b. Faktor Penutur}

Pembicara kadang-kadang sengaja bercampur kode terhadap mitra bahasa karena dia mempunyai maksud dan tujuan tertentu. Pembicara kadang-kadang melakukan campur kode antara bahasa yang satu ke bahasa yang lain karena kebiasaan dan kesantaian.

c. Faktor Bahasa

\footnotetext{
${ }^{3}$ Ibid.,
} 
Dalam proses belajar mengajar media yang digunakan dalam berkomunikasi adalah bahasa lisan. Penutur dalam pemakaian bahasanya sering mencampurkannya bahasanya denan bahasa lain sehingga terjadi campur kode. Umpanya hal itu ditempuh dengan jalan menjelaskan atau mengamati istilah-istilah (kata-kata) yang sulit dipahami dengan istilah-istilah atau kata-kata dari bahasa daerah maupun Bahasa Asing sehingga dapat lebih dipahami.

\section{Campur Kode Berdasarkan Macamnya}

Berdasarkan unsur serapan yang menimbulkan terjadinya campur kode itu, campur kode dibagi menjadi tiga bagian (Jendre, 2001). Bagian-bagian tersebut akan diuraikan di bawah ini.

a. Campur Kode ke Luar (outer code mixing)

Dalam hal ini, "campur kode keluar adalah campur kode yang menyerap unsurunsur bahasa asing" (Jendre, 2001:132). Misalnya, dalam peristiwa campur kode pada pemakaian bahasa Indonesia terdapat sisipan dari bahasa asing seperti bahas Inggris, bahasa Arab, bahasa Jepang, bahasa Cina, dan lain sebagainya.

b. Campur Kode ke Dalam (Inner Code Mixing)

Mengenai definisi tentang campur kode ke dalam, ada beberapa ahli yang memiliki pandangan yang hampir sama. Suwito (1983) mengatakan bahwa seorang yang dalam pemakaian bahasa Indonesianya banyak menyisipkan unsur- unsur bahasa daerah, atau sebaliknya. Maka, penutur tersebut bercampur kode ke dalam. Sementara itu, Jendre (1991) menyatakan campur kode ke dalam adalah jenis kode yang menyerap unsurunsur bahasa daerah yang sekerabat. Umpamanya gejala campur kode pada peristiwa tururan bahasa Indonesia terdapat di dalamnya unsur-unsur bahasa daerah seperti bahasa sumabwa, Lombok, bima, bahasa jawa, dan sebagainya.

\section{c. Campur Kode Campuran}

Definisi mengenai campur kode campuran ialah "campur kode yang di dalam (mungkin klausa atau kalimat) telah menyerap unsur bahasa Sumbawa/Lombok/Jawa (bahasa daerah) dan bahasa asing" (Jendra, 1991:132). Selanjutnya Jendra (1991) lebih tegas mengatakan bahwa campur kode campuran merupakan unsur serapan yang 
diterima oleh bahasa penyerap dengan pembagian menjadi dua bagian seprti (inner dan outer code mixing) telah pula dilakukan.

3. Bentuk-bentuk campur kode

Berdasarkan unsur-unsur kebahasaan yang terlibat didalamnya campur kode menjadi beberapa macam antara lain :

a. Penyisipan unsur-unsur yang berwujud kata

Kata merupakan unsur terkecil dalam pembentukan kalimat yang sangat penting dalam tata bahasa, yang dimaksud dalam kata adalah satuan bahasa yang berdiri sendiri, terdiri dari morfem tunggal atau gabungan morfem.

b. Penyisipan unsur-unsur yang berwujud frasa

Frasa adalah gabungan dua kata atau lebih yang sifatnya tidak prediktif, gabungan itu dapat dan dapat renggang (Harimurti,2001:59)

c. Penyisipan unsur-unsur berwujud klausa

Klausa adalah satuan gramatikal berupa gabungan kata, sekurang-kurangnya terdiri atas subjek dan predikat (Kridalaksana, 1985:151) ${ }^{4}$

\section{Hasil dan Pembahasan}

Berdasarkan hasil penelitian yang peneliti lakukan, maka didalam pembahasan ini akan dipaparkan secara rinci dan faktual hasil dari penelitian dengan judul "Campur Kode Dalam Interaksi Masyarakat Desa Boladangko Kecamatan Kulawi Kabupaten Sigi". Penulis melihat adanya campur kode bahasa kaili (moma) dan bahasa Indonesia. Campur kode tersebut terjadi karena penutur lupa dengan bahasa daerahnya, sehingga penutur yang terkadang sengaja melakukan campur kode karena kebiasaan dan kesantaian berbicara, serta perubahan cara berkomunikasi antara penutur dan lawan tuturnya.

Berdasarkan bentuknya berikut uraian mengenai bentuk-bentuk campur kode yang terjadi dalam proses interaksi masyarakat desa boladangko kecamatan kulawi kabupaten sigi yaitu bentuk campur kode dan campur kode berdasarkan ciri kelas kata.

\footnotetext{
${ }^{4}$ Kridalaksana, Harimurti, Kamus Linguistik, ( Jakarta: PT. Gramedia. 1985) h. 151
} 
1. Penyisipan unsur yang berwujud afiks

Afiks atau imbuhan adalah bunyi yang ditambahkan pada sebuah kata entah diawal, diakhir, ditengah, atau gabungan diantara tiga imbuhan itu untuk membentuk kata baru yang artinya berhubungan dengan kata yang pertama.

Bentuk campur kode penyisipan unsur-unsur yang berwujud afiks dalam interaksi masyarakat desa boladangko kecamatan kulawi kabupaten sigi di uraikan pada data dibawah ini.

(1)

Ica : Pea olu, ponikaa hema die?

Jein : Ponika nanu dikovole, moma ncani mu anaknya virna, eva ele.

Ica : Oh, kakak Eva. Yang bidan itu?

Jein : Hante roy, iyo etu mile.

Konteks : Percakapan terjadi dirumah Ica. Para pembicara yang terlibat dalam tuturan ini adalah Ica dan Jein. Mereka adalah Pemudi masyarakat Desa Boladangko.

Kata yang bercetak miring diatas adalah Campur Kode dalam bentuk penyisipan unsur yang berwujud afiks ncani mu yang dalam bahasa Indonesia berarti kamu tahu.

2. Penyisipan unsur yang berwujud klausa

Klausa sebagai satuan gramatikal yang berupa kelompok kata yang sekurangkurangnya terdiri dari subjek dan predikat serta mempunyai potensi untuk menjadi kalimat.

Bentuk campur kode penyisipan unsur-unsur yang berwujud klausa dalam interaksi masyarakat desa Boladangko kecamatan Kulawi kabupaten Sigi di uraikan pada data dibawah ini.

(2)

Wiwin : Dikase tau tiada ba dengar, ku kaloti moko mei (membentak anaknya yang sedang makan langsat)

Tini : Beva na dea gaga di langsat koni na e.

Amar : Langsat diwarung Ika e, mi na momi baru, 
tiada air minum na onco dimi (tertawa).

Konteks : Percakapan terjadi dirumah mama Heli. Para pembicara yang terlibat dalam tuturan ini adalah Amar, Tini dan Wiwin. Mereka adalah masyarakat Desa Boladangko.

Kata yang bercetak miring diatas adalah Campur Kode dalam bentuk penyisipan unsur yang berwujud klausa Langsat diwarung Ika e, mi na momi yang dalam bahasa Indonesia berarti Langsat diwarung Ika itu, tidak manis .

3 Penyisipan unsur-unsur yang berwujud kata

Kata merupakan unsur terkecil dalam pembentukan kalimat yang sangat penting dalam tata bahasa, yang dimaksud dalam kata adalah satuan bahasa yang berdiri sendiri, terdiri dari morfem tunggal atau gabungan morfem.

Bentuk campur kode penyisipan unsur-unsur yang berwujud kata dalam interaksi masyarakat desa boladangko kecamatan kulawi kabupaten sigi di uraikan pada data dibawah ini.

\section{(3)}

Mama Niar : Mpali napa dako mangke?

Japara : Manuku elenaria hilomu?

Mama Niar : Naria hiloku, disini tadi.

Japara : Oh sudah lama?

Mama Niar : Baru-baru, poma nahae bo. Hangkua di olina manumu?

Japara : Seratus dua puluh ribu ele, Ncanimu manuku?

Mama Niar : Iyo, ncaniku moto i.

Konteks : Percakapan terjadi didepan rumah mama Niar. Para pembicara yang terlibat dalam tuturan tersebut adalah Mama Niar dan Japara. Mereka adalah masyarakat di Desa Boladangko. 
Kata yang bercetak miring diatas adalah Campur Kode dalam bentuk penyisipan unsur yang berwujud kata Hangkua yang dalam bahasa Indonesia berarti berapa.

4. Penyisipan unsur-unsur yang berwujud Frasa

Dari hasil penelitian, ditemukan beberapa campur kode dalam bentuk frasa. Berdasarkan distribusi dalam kalimat frasa endosentris dan frasa eksosentris. Berikut akan peneliti uraikan dibawah ini.

a. Frasa Endosentris

Adalah Frasa Endosentris yang semua unsurnya merupakan unsur pusat. Untuk dua unsur pusat yang mempunyai arti yang berbeda, maka diberi sisipan kata hubung.

(6)

Ica: Pea olu, ponikaa hema die?

Jein : Ponika nanu dikovole, moma ncanimu anaknya virna, eva ele.

Ica: Oh, kakak Eva. Yang bidan itu?

Jein : Hante roy, iyo etu mile.

Ica : Ina, mate ada ei na ruginya jo saya.

Jein : Na rugi ko, ncani mu kau tau naria tina sipa ele, hante anaknya.

Ica: Hema-hema?

Jein : Tina sipa bante ananya ele.

Ica $\quad:$ Oh iyo, ncaniku tobolaria to?

Jein : Momi na bisa lai taha po dero ramei bo.

Ica : Ncaniku ami mi hipa ra etu.

Jein : Iyo, ve mpu di.

Ica : Tina bante ana na etu. Beh, pokonya nabibali aga.

Jein : Ane mu bilo ra mo goyang. Oh na tantu na kanca po goyang ra bo.

Konteks : Percakapan terjadi dirumah Ica. Para pembicara yang terlibat dalam tuturan ini adalah Ica dan Jein. Mereka Pemudi adalah masyarakat Desa Boladangko. 
Kata yang bercetak miring diatas adalah Campur Kode dalam bentuk Frasa Endosentris Koordinatif. Campur Kode tersebut menyelipkan kata bahasa Kaili ke dalam bahasa Indonesia. Bentuk kata tersebut adalah Tina hante ana (Mama dan anak).

b. Frasa Eksosentris

Kebalikan dari frasa endosentris, frasa eksosentris adalah frasa yang justru tidak memiliki unsur pusat. Sehingga, tidak ada satu unsur yang dapat menggantikan unsur lainnya.frasa ini biasa dibentuk oleh preposisi (Kata ganti), Konjungsi (kata sambung) dan nomina (Kata benda).

(7)

Mama Niar : Mpali napa dako mangke?

Japara : Manuku elenaria bilomu?

Mama Niar : Naria biloku, disini tadi.

Japara : Oh sudah lama?

Mama Niar : Baru-baru, poma nabae bo. Hangkua di olina manumu?

Japara : Seratus dua puluh ribu ele, Ncanimu manuku?

Mama Niar : Iyo, ncaniku moto $i$.

Japara : Ane ncanimu, biaba nouru rima i?

Mama Niar : Coba hilo talikuana ria.

Japara $\quad$ : Oh iyo, terimakasih ei mpu tona bula mama niar.

Konteks : Percakapan terjadi didepan rumah mama Niar. Para pembicara yang terlibat dalam tuturan tersebut adalah Mama Niar dan Japara. Mereka adalah masyarakat di Desa Boladangko.

Kata yang bercetak miring pada data diatas adalah Campur Kode dalam bentuk Frasa Eksosentris Direktif. Campur Kode tersebut menyelipkan kata bahasa Kaili ke dalam Bhasa Indonesia. Bentuk kata tersebut adalah Talikuana (dibelakang). 


\section{Penyebab Terjadinya Campur Kode dalam interaksi Masyarakat}

Campur kode tidak muncul karena tuntutan situasi, tetapi ada hal lain yang menjadi faktor terjadinya campur kode itu. Masyarakat Desa Boladangko, melakukan komunikasi tidak dituntut oleh situasi dan konteks pembicaraan, adanya ketergantungan bahasa yang mengutamakn peran dan fungsi pembicaraan yang biasanya terjadi pada masyarakat Desa Boladangko.

Berdasarkan hal tersebut, peneliti menemukan beberapa faktor yang melatar belakangi dan yang mempengaruhi oleh terjadinya Campur Kode di Desa Boladangko beberapa hal yaitu :

1. Penutur lupa dengan Bahasa Daerah

Salah satu penyebab terjadinya Campur Kode karena penutur lupa dengan bahasa daerahnya sehingga si penutur melakukan Campur Kode untuk meneruskan perkataannya.

2. Penutur

Penutur sengaja melakukan Campur Kode terhadap lawan bicaranya karena dia mempunyai maksud dan tujuan tertentu. Yaitu karena kesantaian dan kebiasaan dalam berbicara, sehingga menyisipkan bahasa Indonesia didalam bahasa Daerah tersebut.

3. Perubahan cara berkomunikasi

Sangat sulit untuk mengubah atau mengganti bahasa yang biasa kita pergunakan sebagai alat dengan seseorang. Kebiasaan ini telah membuadaya. Biasanya bahasa yang dipakai telah menjadi suatu batasan hubungan dan wadah segala pengetahuan dan pengalaman yang didapatkan.

Berdasarkan uraian diatas, dapat dikatakan bahwa penggunaan tutur bahasa masyarakat Desa Boladangko Kecamatan Kulawi yaitu dengan menggunakan Campur Kode Bahasa Kaili (Moma) dan Indonesia.

\section{Kesimpulan dan Saran}

\section{Kesimpulan}

Masyarakat Desa Boladangko Kecamatan Kulawi Kabupaten Sigi dikenal sebagai masyarakat asli suku kaili (Moma). Penggunaan bahasa kaili dan Indonesia ketika 
berinteraksi dengan lingkungannya, sangat terasa, hal ini terbukti dengan temuan peneliti bahwa masyarakat Desa Boladangko berkomunikasi dengan dua bahasa yaitu :Bahasa Kaili (Moma) dan Bahasa Indonesia.

Bentuk Campur Kode terhadap bahasa yang digunakan oleh masyarakat Desa Boladangko dalam peristiwa tutur, ada kalanya penutur dan mitra tutur masing-masing mempertahankan bahasa yang digunakannya sesuai latar belakang penutur dan mitra tutur. Hal itu berarti menyalahi prinsip Presiden yang berarti penutur menyusuaikan tuturan dengan tuturan yang sudah terjadi sebelumnya.

Selain itu, masayarakat Desa Boladangko dalam Interaksi Sosialnya sering pula melakukan Campur Kode secara spontanitas ketika ada lawan bicara.dengan demikian maka penelitian Campur Kode dalam Interaksi Masyarakat Desa Boladangko pada umumya besikap positif terhadap bahasa Kaili dan bahasa Indonesia.

\section{Saran}

Berdasarkan hasil penelitian diatas, penulis menyetujui diterapkannya Campur Kode Bahasa Indonesia ataupun bahasa Kaili ke dala Bahasa Indonesia dalam aktifitas sehari-hari.

Para pendengar dapat memperkaya kosa kata dalam Bahasa Indonesia ataupun Bahasa Kaili. Akan tetapi pemakainya bahasa Indonesia jangan sampai diabaikan, apabila terdapat padanan kata yang tepat dalam bahasa indonesia, penulis menyarankan lebih baik menggunakan bahasa Indonesia yang baik dan benar. Penulis menyarankan kepada peneliti selanjutnya untuk meneliti tentang Campur Kode dilihat dari sudut pandang yang lain dari penilitian ini.

\section{Daftar Pustaka}

Alwasilah, Chaedar. Sosiologi Bahasa . Bandung: Angkasa. 1985

Arikunto, Suharsimi . Prosedur Penelitian Suatu Pendekatan Praktik. Jakarta: Rineka Cipta. 2006

Chaer, Abdul. Linguistik Umum. Jakarta: Rineka Cipta. 2003 
Dardjowidjojo. Pengantar Pemahaman Bahasa. Unika Atma Jaya. 2003.

Departemen Pendidikan Nasional. Kamus Besar Bahasa Indonesia Pusat Bahasa Edisi Keempat. Jakarta: PT Gramedia Pustaka Utama, 2008

Kridalaksana, Harimurti, Kamus Linguistik, Jakarta: PT. Gramedia. 1985

Lexy J. Moleong, Metodelogi Penelitian Kualitati, Bandung: Remaja Rosdakarya, 2009

LPM IAIN Palu, Buku Pedoman penulisan karya ilmiyah Tesis, Skripsi, Disertasi, Makalah, 2015

Miles, Matthew B. Dan A. Michael Huberman. Analisis Data Kualitatif. Jakarta: Tjetjep. R.R, Trans, Universitas Indonesia, 1992

Moleong, Lexy J. Metodelogi Penelitian Kualitatif.Bandung: Remaja Rosdakarya, 2009

M.S Mahsun. Metode Penelitian Bahasa. Jakarta: PT Raja Grafindo Persada. 2007

Nababan, P.W. J. Sosio Linguistik Suatu Pengantar. Jakarta: PT. Gramedia 1986

Ohoiwutun, Paul. Sosiolinguistik Memahami Bahasa Dalam Konteks Masyarakat dan Kebudayaan. Jakarta: Kesain Blanc. 1997

Putrayasa I.B. Analisis Kalimat (fungsi, kategori dan Peran). Singaraja, 2006

Sugiyono, Memahami Penelitian Kualitatif, Bandung: Alfabeta, 2008

Suwito. Pengertian Kedwibahasaan. Jakarta: Balai Pustaka. 1990

--------Pengantar Awal Sosiolinguistik Teori dan problema. Surakarta: Henari Offset Solo, 1985

Suyasni N.M.. Campur Kode dalam Kegiatan Jual Beli DiPasar Malam Desa Sumbersari Kecamatan Parigi Selatan. Fakultas Keguruan dan Ilmu Pendidikan Bahasa dan Sastra Indonesia Universitas Alkhairaat Palu. Skripsi tidak diterbitkan 2017

http:/ /raufm.com/diakses pada 01 januari 2017 pada pukul 13.50 WITA.

http:/ / muharrambanget.blogspot.co.id/2008/11/faktor-penyebab-campur-kode.htm/ diakses pada 15 januari 2017 pada pukul 16.23 WITA.

http://meylanarzhanty.blogspot.co.id/2012/09/alih-kode-dan-campur-kodepada.html/ diakses pada 15 januari 2017 pada pukul 16.50 WITA. 